\title{
Tuberculosis in the 1990s: From bedside to bench and back
}

\author{
Frances B Jamieson MD FRCPC, Pamela Chedore MLT \\ Clinical and Environmental Microbiology, Central Public Health Laboratory, Laboratory \\ Services, Ontario Ministry of Health, Etobicoke, Ontario
}

\begin{abstract}
FB Jamieson, $P$ Chedore. Tuberculosis in the 1990s: From bedside to bench and back. Can Respir J 1999;6(4):341-344.
\end{abstract}

Since the mid-1980s, the rate of new cases of tuberculosis (TB) diagnosed in Canada ceased to follow a downward trend, and has instead stabilized at approximately sseven cases/100,000 population. In the United States, a similar trend emerged, such that in the early 1990s there was an increase in new cases of TB. Outbreaks of drug-resistant TB also occurred with devastating clinical impact. These observations prompted laboratories to re-examine their role in halting the spread of TB. Laboratories play a critical part in the diagnosis of TB; procedures must be optimized to provide rapid and accurate results. This review discusses the role of the mycobacteriology laboratory in the diagnosis of TB, and how new technologies available today have enhanced the ability of the laboratory to provide timely, efficient and accurate results.

Key Words: Mycobacteriology laboratory; Tuberculosis

\section{La tuberculose dans les années 90 : du chevet du malade au laboratoire et du laboratoire au che- vet}

RÉSUMÉ : Depuis le milieu des années 80, le taux des nouveaux cas de tuberculose (TB) diagnostiqués au Canada a cessé de suivre une tendance à la baisse, et s'est plutôt stabilisé à environ 7 cas/100,000 personnes. Aux États-Unis, une tendance similaire a émergé, de telle sorte que dès le début des années 90 , il y a eu une augmentation des nouveaux cas de TB. Des flambées de TB chimiorésistante sont aussi survenues et dont l'impact clinique a été dévastateur. Ces observations ont incité les laboratoires à réexaminer leur rôle dans l'enraiement de la dissémination de la TB. Les laboratoires jouent un rôle crucial dans le diagnostic de la TB ; les méthodes doivent être optimisées pour fournir des résultats rapides et précis. Le présent article examine le rôle du laboratoire de mycobactériologie dans le diagnostic de la TB, et comment les nouvelles techniques actuellement disponibles ont amélioré la capacité de ce laboratoire à fournir des résultats opportuns, précis et efficaces.
$I^{2}$ 1993, Tenover et al (1) challenged the clinical mycobacteriology laboratories with an editorial entitled '....Is your laboratory ready?'. This was in response to a resurgence of clinical tuberculosis (TB) in the United States that occurred in the late 1980s after decades of decreasing rates.

In Canada, after a previous downward trend, the rate of new cases of TB has stabilized at approximately 7 cases/100,000 population/year (2). Over the past few years, increasing resistance of Mycobacterium tuberculosis
(Mtb) to first-line drug therapy has also become a problem both worldwide and in Canada, particularly in Ontario (3).

Definitive diagnosis of TB depends on the isolation and identification of $\mathrm{Mtb}$, and appropriate therapeutic decisions are based on the result of anti-TB drug susceptibility testing. The laboratory plays a critical role in the control of TB by providing rapid identification of Mtb in patient specimens and drug susceptibility testing results, allowing for the provi-

Correspondence and reprints: Dr Frances B Jamieson, Clinical and Environmental Microbiology, Central Public Health Laboratory, Laboratory Services, Ontario Ministry of Health, 81 Resources Road, Etobicoke, Ontario M9P 3T1. Telephone 416-235-5841,

fax 416-235-5951, e-mail frances.jamieson@moh.gov.on.ca 
TABLE 1

Specimen requirements for mycobacteriology

\begin{tabular}{|c|c|c|c|}
\hline Specimen type & Specimen requirements & Special instructions & Unacceptable specimens \\
\hline $\begin{array}{l}\text { Bronchoalveolar } \\
\text { lavage or bronchial } \\
\text { washings }\end{array}$ & Submit $\geq 5 \mathrm{~mL}$ in a sterile container & $\begin{array}{l}\text { Avoid contaminating bronchoscope with tap } \\
\text { water which may contain saprophytic } \\
\text { mycobacteria }\end{array}$ & \\
\hline Cerebrospinal fluid & Submit $\geq 3 \mathrm{~mL}$ in sterile container & Submit maximum volume obtainable & \\
\hline $\begin{array}{l}\text { Fluids (pleural, } \\
\text { pericardial, etc) }\end{array}$ & $\begin{array}{l}\text { Submit as much as possible } \\
\text { (minimum } 10 \mathrm{~mL} \text { ) in a sterile } \\
\text { container(s). For follow-up of } \\
\text { patients on therapy resubmit } \\
\text { sputa at the end of the second } \\
\text { month of treatment and at the end } \\
\text { of therapy }\end{array}$ & $\begin{array}{l}\text { Disinfect site with alcohol if specimen is } \\
\text { collected with a needle and syringe. The } \\
\text { addition of heparin or sodium } \\
\text { polyanethole-sulphonate is helpful if the } \\
\text { specimen contains fibrinogen }\end{array}$ & \\
\hline Gastric washings & $\begin{array}{l}\text { Submit more than } 5 \mathrm{~mL} \text { in a sterile } \\
\text { container }\end{array}$ & $\begin{array}{l}\text { Use sterile saline for lavage. Collect fasting, } \\
\text { early morning specimens on three } \\
\text { consecutive days. Neutralize the specimen } \\
\text { with } 100 \mathrm{mg} \text { sodium carbonate if the delay } \\
\text { between collection and processing is more } \\
\text { than } 48 \mathrm{~h}\end{array}$ & $\begin{array}{l}\text { Specimen that has not been } \\
\text { neutralized }\end{array}$ \\
\hline Sputum & $\begin{array}{l}\text { Submit } \geq 5 \mathrm{~mL} \text { in a nonwaxed, } \\
\text { sterile container. Collect an early } \\
\text { morning specimen on three } \\
\text { consecutive days from a deep, } \\
\text { productive cough. Do not pool } \\
\text { specimens. To verify tratment } \\
\text { success, repeat sputum } \\
\text { examinations should be } \\
\text { performed at the end of the } \\
\text { second month of treatment and at } \\
\text { the end of therapy. }\end{array}$ & $\begin{array}{l}\text { Expectorated sputum: instruct patient on how } \\
\text { to produce sputum as distinct from saliva or } \\
\text { nasopharyngeal discharge } \\
\text { Induced sputum: use sterile hypertonic saline. } \\
\text { Avoid sputum contamination with nebulizer } \\
\text { reservoir water }\end{array}$ & $\begin{array}{l}24 \mathrm{~h} \text { pooled specimens, } \\
\text { saliva }\end{array}$ \\
\hline Tissues & $\begin{array}{l}\text { Submit tissue in a sterile container } \\
\text { without fixative or preservative }\end{array}$ & $\begin{array}{l}\text { Collect aseptically. Select caseous portion if } \\
\text { available Do not wrap in gauze or freeze. } \\
\text { Indicate specimen site }\end{array}$ & $\begin{array}{l}\text { Specimen submitted in } \\
\text { formalin }\end{array}$ \\
\hline
\end{tabular}

Specimen types are limited due to space constraints. All specimens should be submitted to the laboratory as soon as possible to avoid possible overgrowth by contaminating microbiota. Specimens delayed in transit should be refrigerated but not frozen

sion of optimal medical care, infection control and public health management of TB patients.

The mycobacteriology laboratory of today must be capable of providing rapid turn-around times (TATs). This review discusses how to use the mycobacteriology laboratory optimally for the diagnosis of TB and how new technologies have allowed the clinical laboratory to provide results in an efficient, timely and accurate manner.

\section{SPECIMEN COLLECTION}

Results from laboratory testing are only as good as the specimens submitted. Proper specimen collection and transport to the laboratory are essential for the rapid, accurate diagnosis of TB. The most commonly submitted specimen is sputum. Sputum specimens should be obtained from deep, productive coughs in the early morning on three consecutive days; specimens should not be pooled. A summary of requirements for optimal specimen collection and special specimens (eg, cerebrospinal fluid), transportation and TATs can be found in Table 1.

\section{LABORATORY DIAGNOSIS}

The pathways taken by a specimen through the mycobacteriology laboratory for the diagnosis of TB are illustrated in Figure 1.
Microbiological analysis: The acid-fast smear is still the most inexpensive and easiest test to perform, which will quickly provide important, initial information for the clinician. This test is based on the unique mycobacterial cell wall that is responsible for its 'acid-fastness', but that also allows it to resist decontamination agents used to prepare specimens for culture (4). A rapid TAT increases the impact of this test, and results should be available to clinicians within $24 \mathrm{~h}$ of specimen receipt at the laboratory. However, organisms seen on a smear cannot be speciated. Therefore, the presence of any mycobacterial species may give a positive result. As well, the sensitivity is quite low, because a positive smear requires the presence of at least $5 \times 10^{3}$ bacilli/mL of specimen (5). The sensitivity can be improved by using a fluorescent staining method, which allows the use of lower magnification on the microscope for faster screening.

Examination of smears from at least two specimens generally will detect most smear-positive cases. If the first two smears are positive, further samples of the same type will not improve the result (6).

At the same time as the specimen is processed for the acid-fast smear, it is also set-up for culture. On average, approximately $1 \times 10^{2}$ viable bacilli/mL of specimen are necessary for a positive culture. In the past, six to eight weeks were necessary for the culture of Mtb using solid media. The intro- 
duction of liquid, automated culture methods has greatly improved TAT for culture results. On average, liquid culture systems yield results one to two weeks earlier than conventional solid media (7). A positive culture may be detected eight to 14 days from the receipt of the specimen. Culture methods should include a liquid and solid medium (1), because there are some isolates (especially nontuberculous mycobacteria) that may not grow in liquid culture.

Identification of Mtb can be accomplished by a variety of methods. The nonisotopic DNA probe technique is well established, easy to perform and has a TAT of a few hours (8). Thus, a positive culture isolate may be identified and reported as Mtb complex the same day that the culture becomes positive. Further testing is necessary to distinguish Mycobacterium bovis within the complex.

Susceptibility testing: Susceptibility testing can be performed using three recognized methods; however, the liquid broth radiometric method provides the most rapid results. In Ontario, strains are tested against the five first-line antituberculous drugs: isoniazid, rifampin, ethambutol, streptomycin and pyrazinamide. Using the liquid broth radiometric method, results are generated, on average, within six days of set-up. Detection of resistance to any two or more of these drugs necessitates further testing of second-line antituberculous drugs.

\section{NEW TECHNOLOGIES}

Direct detection of Mtb from specimens: Molecular biological techniques have led to the development of rapid and accurate tests that can directly detect the presence of $\mathrm{Mtb}$ DNA or RNA in specimens. Two systems have been approved by the United States Food and Drug Administration for use on smear-positive respiratory specimens. Both systems rely on 'amplification' of DNA or RNA to a level that can be easily detected. Theoretically, amplification methods can detect one organism; however, the usual detectable range is 50 to 100 organisms $/ \mathrm{mL}$ of specimen. The system in use at the Central Public Health Laboratory (CPHL) in Ontario is the Amplified Mycobacterium Tuberculosis Direct Test (Gen-Probe, San Diego, California) or MTD. Numerous studies have confirmed a sensitivity and specificity well over 95\% in smear-positive respiratory specimens (9-11). Our own experience has documented a sensitivity, specificity, positive predictive value and negative predictive values of $97.2 \%, 99.7 \%, 97 \%$ and $99.4 \%$, respectively. All smearpositive specimens as well as selected smear-negative (based on a clinical suspicion of TB) are tested. Direct detection in specimens using this technology has allowed our laboratory to detect cases of smear-negative TB from cerebrospinal fluid specimens on the same day as the specimen was received in the laboratory.

Formalin fixed specimens that have not been submitted for culture but that appear suspicious for TB on histopathological analysis may be analyzed for the presence of $\mathrm{Mtb}$ DNA. Methods for the extraction of DNA from formalinfixed and paraffin embedded tissues have been developed that allow for amplification of Mtb DNA using the po-

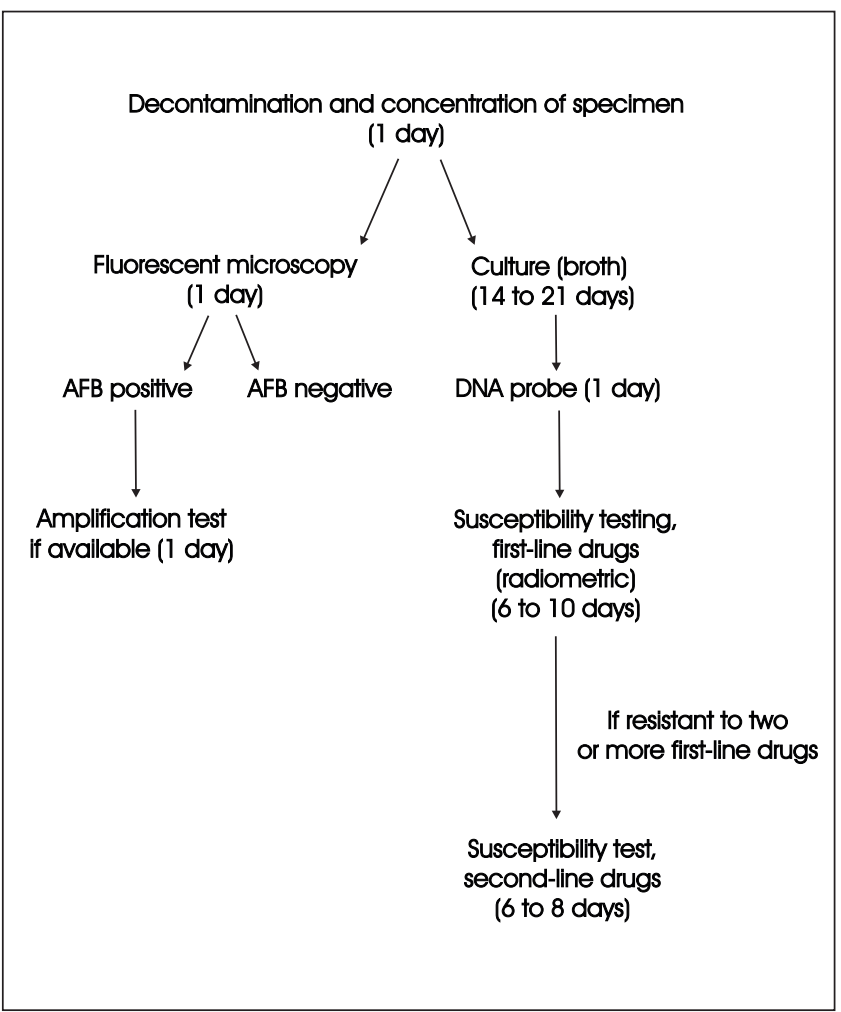

Figure 1) Laboratory diagnosis of tuberculosis. Turn-around times may vary according to the testing frequency of individual laboratories

lymerase chain reaction (12). These methods have been used successfully at the CPHL.

Other new developments: Emerging drug resistance in TB can be caused by noncompliance to prescribed therapy and/or treatment failure. Treatment failure can be lifethreatening, and drug-resistant TB poses a serious health risk. Therapeutic drug monitoring is available to determine whether a patient is achieving appropriate serum levels of antituberculous medications (13). Using high performance liquid chromatography analysis, drug levels may be determined accurately and rapidly to assist clinicians in the treatment of patients with TB. Assays have been developed at the Drug Testing Laboratory, CPHL, for all five first-line antituberculous drugs as well as to two of the second-line drugs (ciprofloxacin, Cipro, Bayer Inc, Etobicoke, Ontario and clofazimine). Molecular tests are being developed to detect the genes responsible for resistance to antituberculous drugs; these tests would assist in determining an effective therapeutic protocol.

Molecular methods have been developed that allow distinct 'DNA fingerprints' to be produced from Mtb isolates. DNA fingerprinting is used in epidemiological studies (eg, nosocomial transmission, reactivation of TB versus reinfection, cross-contamination in the laboratory, population studies) to determine the relatedness of Mtb strains. Typing Mtb strains has been very useful in nosocomial outbreaks in hospitals and for relating clusters of recent TB cases. One method, restriction fragment length polymorphism, has been standardized to allow worldwide comparisons of DNA fin- 
gerprints of Mtb strains from different geographic areas (14). Because drug-resistant TB continues to be a problem, typing drug-resistant isolates can be used to provide insight into the source of such isolates and their patterns of spread.

\section{CONCLUSIONS}

Many new laboratory methods have become available within the past several years to allow mycobacteriology laboratories to improve their diagnostic capabilities. Clinicians should expect to receive smear results within $24 \mathrm{~h}$ and positive culture reports, with sensitivities, within an average of 21 days of the receipt of the specimens in the laboratory. Molecular testing techniques have been developed that can rapidly identify specific specimens positive for Mtb the same day that they are received for testing in the laboratory. Other tests are available to assist the clinician in monitoring therapy for $\mathrm{TB}$, in detecting Mtb from histopathological specimens and in determining transmission patterns of TB in clinical cases. Future developments include improved culture techniques, detection of resistance genes in Mtb and improved methods to type Mtb isolates rapidly.

\section{REFERENCES}

1. Tenover FC, Crawford JT, Huebner R, et al. The resurgence of tuberculosis: Is your laboratory ready? J Clin Microbiol 1993:31:767-70.

2. Tuberculosis in Canada, 1996. Health Canada. Ottawa, Minister of Public Works and Government Services, 1997.

3. Remis RS, Jamieson F, Haddad A, Chedore P, Vernich L. Increasing resistance of $M$. tuberculosis isolates, Ontario 1987-96. Interscience Conference on Antimicrobial Agents and Chemotherapy. Toronto, September 28 to October 1, 1997, 1997. (Abst E-167)

4. Nolte FS, Metchock B. Mycobacterium. In: Murray PR, Baron EJ,
Pfaller MA, Tenover FC, Yolken RH, eds. Manual of Clinical Microbiology, 6th edn. Washington: American Society for Microbiology, 1995:400-37.

5. Smithwick RW. Laboratory manual for acid-fast microscopy, 2nd edn Atlanta: Centers for Disease Control, 1975.

6. Urbanczik R. Present position of microscopy and of culture in diagnostic mycobacteriology. Zentralbl Bakteriol Hyg [A]. 1985;260:81-7.

7. Abe C, Josojima S, Fukasawa Y, et al. Comparison of MB-Chek, BACTEC and egg-based media for recovery of mycobacteria. J Clin Microbiol 1992;30:878-81.

8. Evans KD, Nakasone AS, Sutherland PA, et al. Identification of Mycobacterium tuberculosis and Mycobacterium avium- $M$. intracellulare directly from primary BACTEC cultures by using acridinium-ester labeled DNA probes. J Clin Microbiol 1992;30:2427-31.

9. Miller N, Hernandez SG, Cleary TJ. Evaluation of Gen-Probe Amplified Mycobacterium Direct Test and PCR for direct detection of Mycobacterium tuberculosis in clinical specimens. J Clin Microbiol 1994;32:393-7.

10. Pfyffer GE, Kissling P, John EMI, et al. Diagnostic performance of amplified Mycobacterium tuberculosis direct test with cerebrospinal fluid, other non-respiratory and respiratory specimens. J Clin Microbiol 1996;34:834-41

11. Gamboa F, Fernandez G, Padilla E, et al. Comparative evaluation of initial and new versions of the Gen-Probe amplified Mycobacterium tuberculosis direct test for direction detection of Mycobacterium tuberculosis in respiratory and non-respiratory specimens. J Clin Microbiol 1998;36:684-9.

12. Marchetti G, Gori A, Catozzi L, et al. Evaluation of PCR in detection of Mycobacterium tuberculosis from formalin-fixed, paraffinembedded tissues: comparison of four amplification assays. J Clin Microbiol 1998;36:1512-7.

13. Peloquin C. Using therapeutic drug monitoring to dose the antimycobacterial drugs. Clin Chest Med 1997;18:79-87.

14. Van Embden JD, Cave MD, Crawford JT, et al. Strain identification of Mycobacterium tuberculosis by DNA fingerprinting: recommendations for a standardized methodology. J Clin Microbiol 1993;31:406-9.

15. The Standards Committee, Canadian Thoracic Society. Canadian Tuberculosis Standards, 4th edn. Gloucester: Canadian Lung Association. 


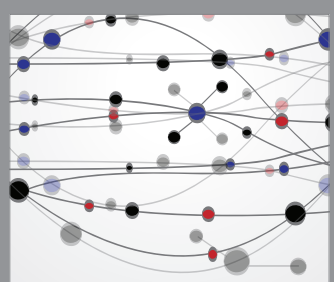

The Scientific World Journal
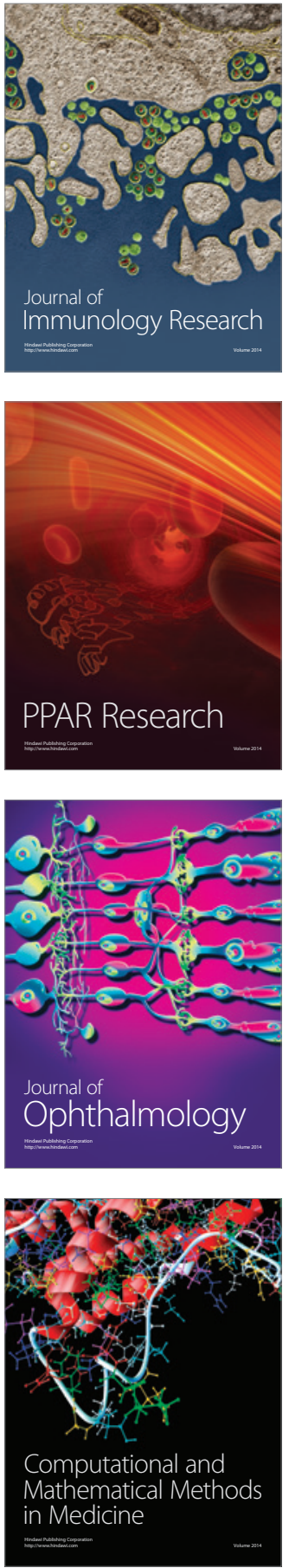

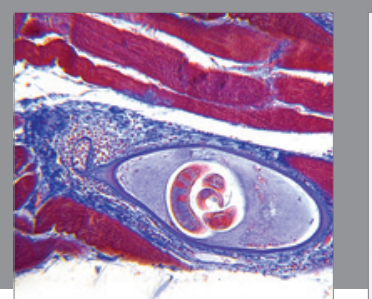

Gastroenterology Research and Practice

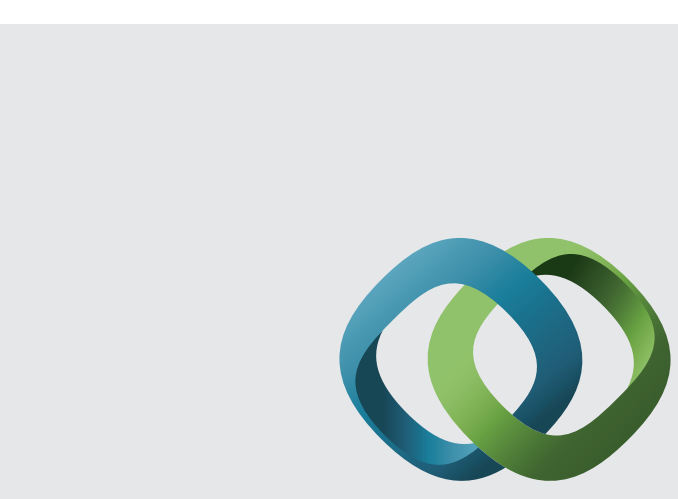

\section{Hindawi}

Submit your manuscripts at

http://www.hindawi.com
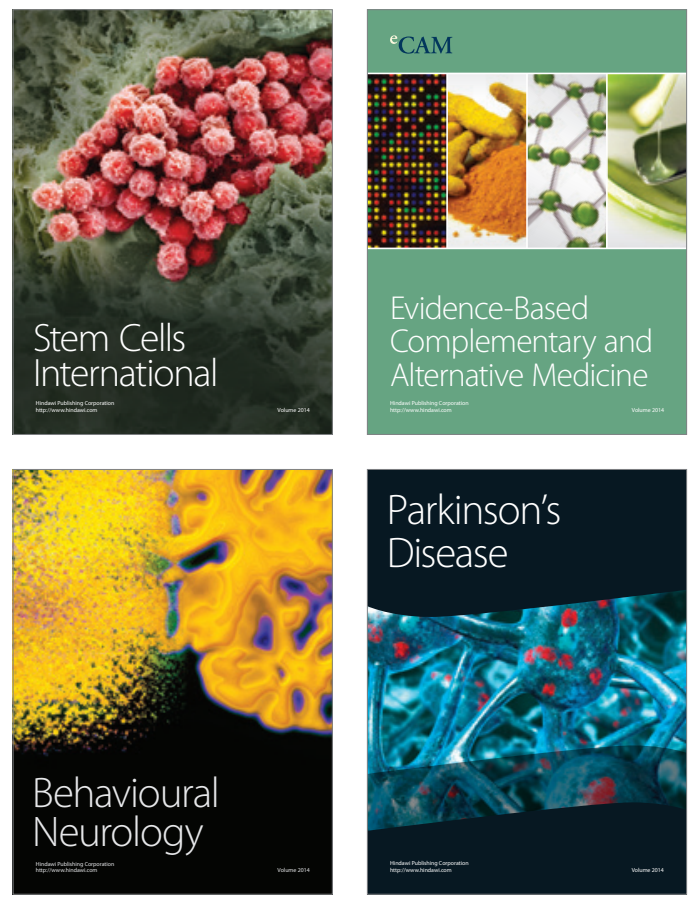
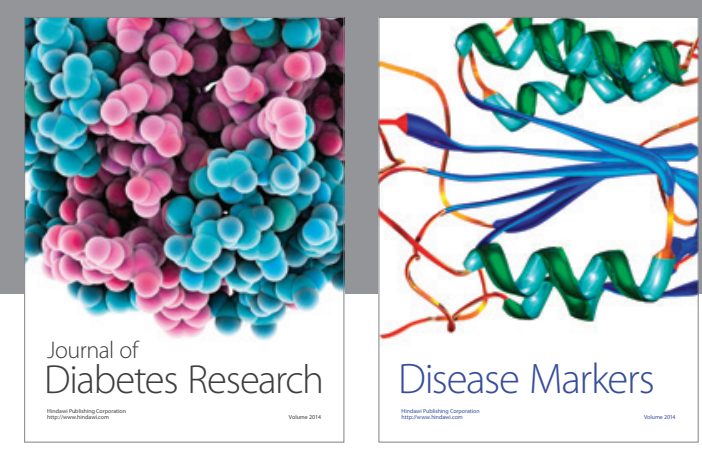

Disease Markers
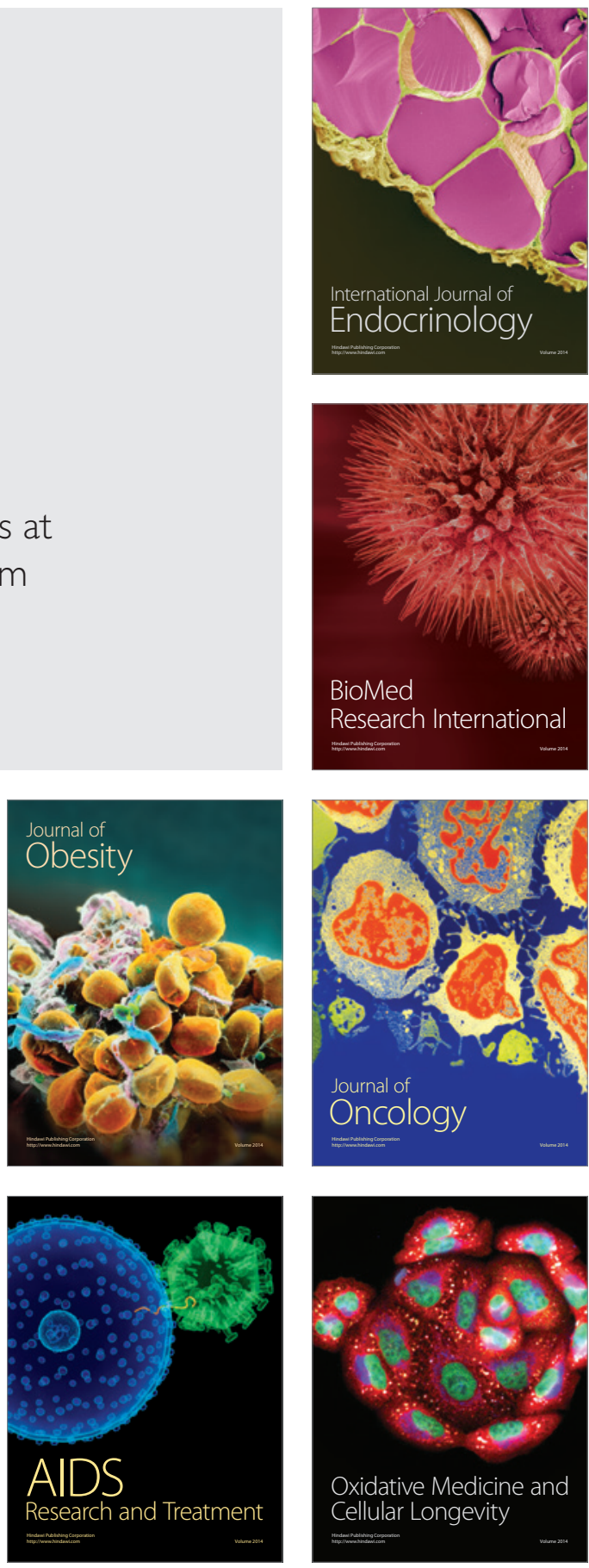